Article

\title{
Sustainable Development of Entrepreneurial Orientation through Social Drivers
}

\author{
Purevdulam Altantsetseg 1,2,3, Alaleh Dadvari ${ }^{4}\left(\mathbb{D}\right.$, , Tsevegjav Munkhdelger $^{1,3}$, \\ Gerelt-Od Lkhagvasuren ${ }^{5}$ and Massoud Moslehpour ${ }^{6,7, * \mathbb{D}}$ \\ 1 Graduate School, Mongolian National University, Ulaanbaatar 14210, Mongolia; \\ a.purevdulam@mnun.edu.mn (P.A.); ts.munkhdelger@mnun.edu.mn (T.M.) \\ 2 Business and Law School, City University of Mongolia, City University, 7th Khoroo, Sukhbaatar District, \\ Ulaanbaatar 14190, Mongolia \\ 3 Graduate School, University of Internal Affairs, 8th Khoroo, Baynzurkh District, \\ Ulaanbaatar 210332, Mongolia \\ 4 Department of Business Administration, National Central University, Zhongli, Taoyuan 320317, Taiwan; \\ dadvari.alaleh@g.ncu.edu.tw \\ 5 Department of Education, Mongolian National University, Ulaanbaatar 14210, Mongolia; \\ gereltod@mnun.edu.mn \\ 6 Department of Business Administration, Asia University, Wufeng District, Taichung City 41354, Taiwan \\ 7 Department of Management, California State University, San Bernardino, CA 92407, USA \\ * Correspondence: writetodrm@gmail.com
}

Received: 26 August 2020; Accepted: 15 October 2020; Published: 23 October 2020

check for updates

\begin{abstract}
Given that social dilemmas such as climate change, unemployment, and public health are growing globally, recognition of social drivers related to sustainable development while generating social impact is of particular interest to professionals and academics. This study aims to highlight the antecedents of sustainable social impact. Thus, we evaluate the association between entrepreneurial orientation and social impact through the mediation effects of social factors named social drivers, including service innovation, social innovation, and social value orientation. The data collection is from the service and non-service industries in Taiwan. A total of 270 samples consisting of employees, managers, SME owners, and CEOs is used. We employed structural equation modeling (SEM) to test the proposed hypotheses. Research findings indicate entrepreneurial orientation is a determining factor of sustainable innovation that not only renders entrepreneurially strategic dispositions of an organization but also significantly contributes to generating drastic social impact. In particular, entrepreneurs are found to be more proactive in solving problematic social issues through their entrepreneurial characteristics. Statistical findings support that all direct effects, besides partial and full mediation, are proved, which reveals the transformative potential of selected social drivers. Altogether, research findings provide exciting insights into entrepreneurship knowledge, innovation, and value assumptions in the social context. We further discuss theoretical and practical implications.
\end{abstract}

Keywords: entrepreneurial orientation (EO); social innovation (SoIn); service innovation (SeIn); social value orientation (SVO); social impact (SoIm); Taiwan

\section{Introduction}

The significance of social development is deemed crucial in society at an early stage of sustainable development. The concept of sustainable development refers to building propositions for achieving human development objectives while simultaneously providing natural systems to render the natural resources and ecosystem services on which the economy and society rely [1]. Therefore, understanding social sustainability and social impact initiatives that can exponentially 
accelerate the development process in different social domains is especially essential. In this vein, entrepreneurial orientation, rooted in determination for excellence, plays an active role in creating sustainable social impact [1].

During the past decade, there have been several studies intended to reveal the importance of studying social impact (SoIm) and its sustainable effect on society's improvement on a large scale [2-5]. In this regard, entrepreneurs at the individual or organizational levels with their unique characteristics, known as entrepreneurial orientation (EO), cooperate to step up social impact through their innovative products or services in several countries.

According to the Global Entrepreneurship Monitor (GEM), entrepreneurs have exhibited immense effort in their business and society annually [6]. Entrepreneurial orientation (EO) refers to a general stance that includes beliefs and values associated with being innovative, risk-taking, and proactive. These highlighted characters, for the most part, belong to entrepreneurs. In other words, individuals with bold EO may tolerate more risk and may act in a more innovative way [7-10]. EO is a crucial factor necessary to run any large or small business successfully.

Moreover, EO performs as a sustainable resource for strategic decisions [11]. Firms with a high degree of EO can easily facilitate innovation in the environment $[7,11]$. Therefore, EO is the entrepreneurial background of a firm. The potential capabilities of entrepreneurial orientation (EO) are connected to the essential determinants of entrepreneurial activities [12,13]. Notably, entrepreneurs, in cultural forms, have been recognized for the impactful contributions that they provide to economic, cultural, environmental, and social wellbeing [14,15]. In this regard, past studies attempt to explore the effectiveness of EO within a management, entrepreneurship, and social science context [16,17]. However, there is a lack of empirical evidence supporting the link between EO and social impact. Previous works did not consider the mediating missing links between EO and social impact. A question that arises is whether EO plays a role in how individual and organization's actions impact on surrounding communities. To fill the research gap and to build on existing scientific studies, we structure a new model to theoretically analyze the effectiveness of entrepreneurial orientation in predicting the sustainable development of the companies. The provided research model measures the transformative potential of social drivers while analyzing the mediating effects. It is worth mentioning that despite the importance of defined factors, surprisingly, scientific evidence and methodological research are lacking.

Corporations are progressively launching initiatives with vibrant social directives. Social impact initiatives of businesses show a link between corporate social initiatives and intermediate employee-related outcomes such as motivation, identification with the firm, and employee retention, as one the most critical aspects of human capital management [18]. Thus, the current study looks at sustainable societal impact initiatives through the lenses of social innovation, service innovation, and social values orientation structures, a new research framework to identify the associations among the constructs of interest.

Social innovation (SoIn) provides creative and innovative solutions to cope with social and global dilemmas that require urgent solutions [19]. SoIn deals with cultural and social institutions and the educational system to improve the standards of life [20]. From the micro-level perspective, scholars view social innovations' emphasis as being on the enrichment of capabilities that improve living standards and enhance the production capacity of an organization. However, others following the macro-level viewpoint argue that social innovation refers to a common transformation in society and sustainable progress [21]. Although the concept of social innovation (SoIn) is not new, applying SoIn to date has remained undiscovered. Little attention has been devoted to the role of social innovation as a source of social change. Early research discusses that social innovation (SoIn) is the consequence of exchanging resources and knowledge by other parties mobilized through legitimization actions [22,23]. Notably, social innovation (SoIn) is a transformative force through the interaction between the agents, organizational structure, environment, and social system [24,25].

In 1986, Messick and McClintock [26] discovered a method to assess individual stimulus to cooperate on social dilemmas. Later, scholars use the term social value orientation (SVO) to represent 
motivational orientation that reflects individual differences in helping society [26,27]. Despite several arguments on SVO terminology, researchers find no distinct definition of social value orientation (SVO), especially within the entrepreneurship research field. Therefore, choosing SVO as a research construct is the claim to originality of this work.

Service innovation (SeIn) is rooted primarily in traditional new product development focusing on tangible goods. According to Den Hertog and Bilderbeek [28], service innovation (SeIn) includes different dimensions such as a new client or service and updated technological choices.

Taiwan is recognized as a prosperous country, implementing strategies and policies to stimulate an entrepreneurial spirit among other nations in the region [29]. The Global Entrepreneurship Monitor reports that Taiwan is among the countries with the highest growth rate of entrepreneurs [6]. We consider Taiwan a prosperous industrial nation in finding sustainable solutions to the social and environmental experiments of business and capital markets functioning together [30]. Thus, Taiwan can be an acceptable role model, especially for the other countries in developing nations of the region. We select Taiwan for this study to explore the interrelationships among the variables. We identify entrepreneurial orientation (EO) as a critical driver of social impact. Figure 1 indicates other crucial and influential elements, including social innovation (SoIn), service innovation (SeIn), and social value orientation (SVO).

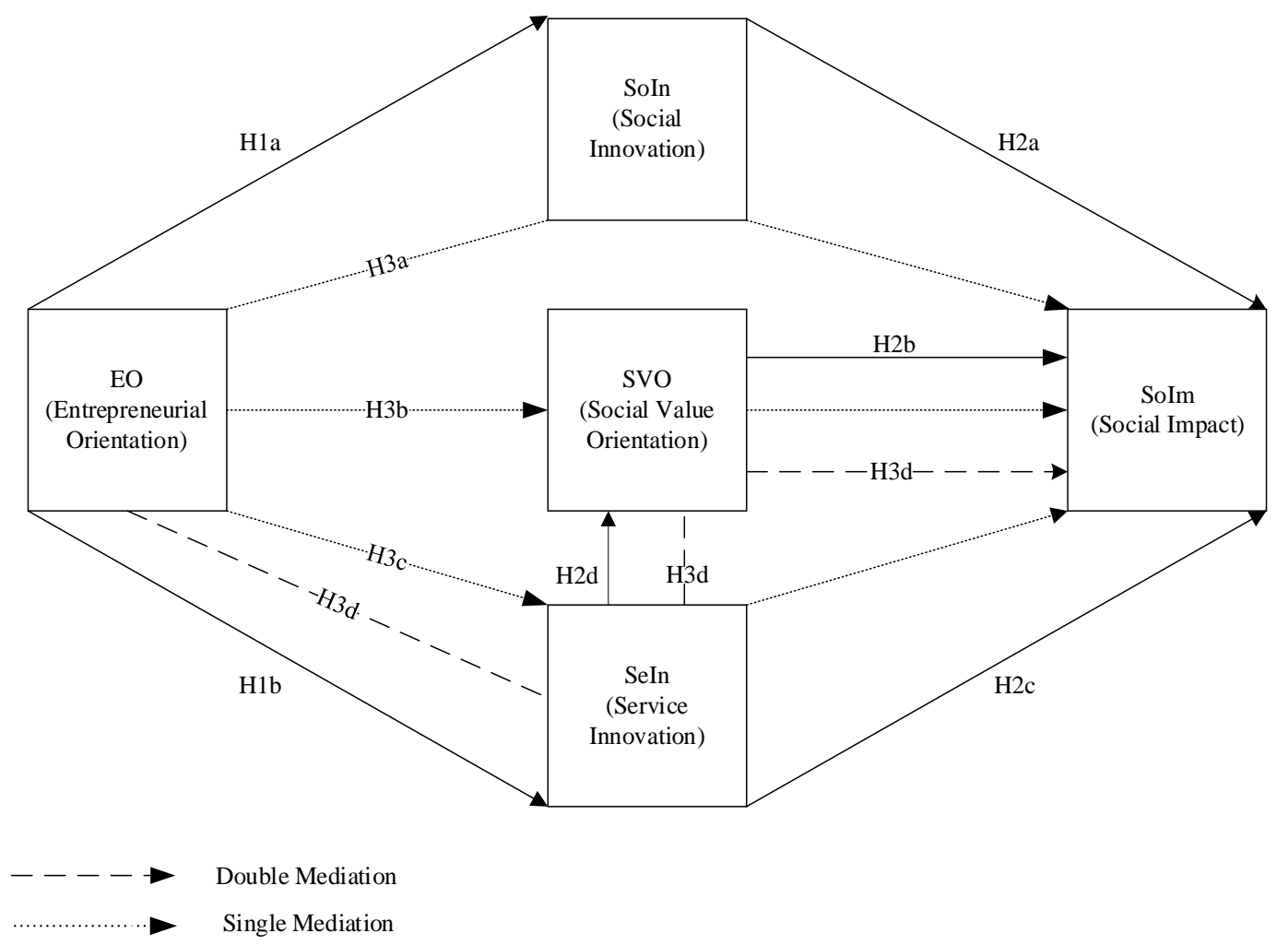

Figure 1. Research framework.

The implications of the study are beneficial to researchers and practitioners, especially in organizations and society aiming to improve strategies and practices or preparing programs related to corporate social sustainability and promoting social innovation to produce considered social benefits. Higher-level managers of private or even public organizations aiming to increase social value orientation will also benefit from the findings by recruiting individuals with a strong EO profile to also boost entrepreneurship at the firm-level. Policymakers may change or provide suitable training and educational courses for employees.

The proposed research model contributes to the theories by exploring the mediating effect of social innovation (SoIn), service innovation (SeIn), and social value orientation (SVO) as a tool for 
socio-economic development. Moreover, based on our findings, future research may expand the model to explore other factors to accelerate the process of creating a social impact on society. The findings of this research indicate that social innovation (SoIn), service innovation (SeIn), and social value orientation (SVO) mediate the relationship between EO and social impact (SoIm) in society. Service innovation (SeIn) and social value orientation (SVO) improve entrepreneurial orientation. It is worth mentioning that entrepreneurial orientation (EO) is most effective when it matches the service innovation (SeIn). Overall, our study offers an innovative model into the entrepreneurial orientation literature to discover sustainable social impact. We seek to contribute to the understanding of the entrepreneurial ecosystem that encompasses the quality of human resources concerning the organization, favorable values, and dominant culture to investigate what drives the dynamics of social impact.

The next section will discuss the development of the research hypotheses.

\section{Literature Review and Hypotheses Development}

This section discusses the research constructs used in this study, including entrepreneurial orientation (EO), social innovation (SoIn), service innovation (SeIn), social value orientation (SVO), and social impact (SoIm). Furthermore, we deliberate on the relationships among the constructs, resulting in the hypothesis building. Previous studies reveal that a successful entrepreneurial process that results in sustainable impact is affected by individual and contextual factors (e.g., human, social, physical, organizational, and technological capital) [31-34]. In other words, interactions between personal backgrounds and social context (e.g., contacts, relationships, and networks) stimulate the entrepreneurial operation, leading to innovation $[35,36]$. The current study relies on entrepreneurial orientation (EO) literature to study the proposed research framework. Figure 1 shows the research model.

\subsection{Entrepreneurial Orientation (EO)}

Entrepreneurial orientation (EO) is related to the practices in which managers of the firm are willing to take risks, favor change, implement innovation, and proactively chase new opportunities [10,37,38]. The EO concept implies that significant entrepreneurial dispositions, including innovativeness, autonomy, risk-taking, proactiveness, and competitive aggressiveness, are related to organizational performance $[9,39]$. Entrepreneurial orientation (EO) is thus an essential indicator of high performing organizations [10]. According to Lumpkin and Dess [13], EO includes a desire to act autonomously, an intention to innovate and take risks, and a willingness to be proactive toward opportunities. Recently, the sustainable growth of organizations has become the primary concern. Assessing sustainable entrepreneurial orientation as a determinant factor is receiving more attention [38,40].

The conceptualization domain of entrepreneurial orientation (EO) is broad. At the same time, several scholars agree on the multi-dimensional notion of it. Another school of thought considers EO as a unidimensional strategic orientation [10] that underlines innovativeness, risk-taking, and proactiveness among the essential characteristics of entrepreneurial companies. It is argued that EO significantly influences an entrepreneur's satisfaction with their activities in society and the growth of the company [41,42].

Contemporary investigations [43-45] deliberate the effectiveness of EO on firms' performance, organizational growth, and social improvement. From the organizational perspective, entrepreneurial orientation (EO) is an embedded organizational philosophy that drives decision-making and behavior towards creating new goods, new methods of production, new markets, or diversification of the business into a new industry [42,46]. A high level of entrepreneurial behaviors positively influences organizational growth [13,41,47,48]. According to Lee and Lim [49], organizations that act independently (autonomy), encourage new ideas (innovativeness), take the initiative (proactiveness), take risks (risk-taking), and aggressively compete in their area posit strong entrepreneurial orientation. 


\subsection{Social and Service Drivers}

Social impact (SoIm) is a significant part of an event linked to entrepreneurship [50]. While existing terminology on social impact (SoIm) suggests different definitions, Moss et al. [50] conceptualize the SoIm construct as a social value. According to social impact theory, SoIm describes how people influence or are influenced by each other during a particular time [51].

Latané and Wolf [51] argue that social impact (SoIm) refers to individuals' thoughts, beliefs, or behavior influenced by the presence or action of another individual. In other words, peoples are affected by several factors engaged in the social environment [4]. Therefore, social innovation (SoIn), social value orientation (SVO), and service innovation (SeIn) all influence social impact. Moreover, consistent with the role of EO that results in creating new ways to develop or improve products and services to revisit user needs and their demands, EO may act as an influential element to generate social impact.

Social innovation (SoIn) is the development and sustainability of ideas and issues ranging in a spectrum from working conditions to education, individual to societal development, monitoring health and environment to climate changes [52]. Alternatively stated, innovative services or activities are stimulated by dealing with social needs to improve the standards of life in diverse areas and promote the development of human resources [53-55]. Scholars describe social innovation (SoIn) as a complex set of processes that link several factors. SoIn links factors such as motives (e.g., social need), outcomes (e.g., activities or services), and areas of change (e.g., organizations) together to let it occurs within networks, at the boundaries of organizations and industries [56]. Regional development is a complicated process, and social innovation (SoIn) acts as the trigger for sustainable development [57].

According to Buchegger and Ornetzeder [21], the main goals of social innovation (SoIn) are categorized into micro (e.g., increasing the production capacity of an organization) and macro (e.g., preparing society for sustainable progress) levels. Despite scholarly interest in social innovation topics, few studies represent its definitions and dimensions. Moreover, researchers find a lack of integration of the existing literature and ambiguity about its scope [58-64]. This study focuses on relevant discussions on social innovation (SoIn) close to the research domain.

Cajaiba-Santana [65] proposes a framework to explain social innovation by introducing new social practices generated from collective, goal-oriented, and intentional actions to cultivate social change. Baturina and Bežovan [63] find modalities for recognition that successfully produce a positive social impact and demonstrate the importance of new efficient solutions. If the firm has entrepreneurial activity and processes, and if entrepreneurs also score highly on entrepreneurial orientation, they may better distribute entrepreneurial culture to society [13]. According to the Bureau of European Policy Advisers (BEPA), social innovation also mobilizes each citizen to become an active part of the innovation process [66]. Taken together, EO manifests itself through promoting a firm's productivity that affects society. Therefore, it is assumed that EO is related to innovations, affecting sustainable social impact.

To define service innovation (SeIn) is problematic, as no common understanding exists about its meaning [67]. Some studies refer to service innovation (SeIn) as the impact of technology [68-70]. Some other previous studies emphasize the intangible nature of service and the contribution of organizational knowledge and non-technological factors [71]. Skålén et al. [72] refer to service innovation (SeIn) to generate new value through integrating practices. Miozzo and Soete [73] provide a more differentiated picture of the services industries, distinguishing between supplier-dominated and information networks. Nowadays, the way an enterprise views the process of innovation has changed [74]. Innovations through the services provided by organizations are another influential factor [75].

According to $\mathrm{Wu}$ et al. [76], the accumulation of social capital and entrepreneurial orientation directly affects promoting innovation. A recent study conducted by Arzubiaga et al. [77] addresses the relationship between entrepreneurial orientation (EO) and innovation in SMEs. Another study by Shan et al. [39] points to the positive relationship between entrepreneurial orientation and speed 
innovation. Additionally, they stress the effectiveness of innovation on firms' performance. Therefore, relying on the above discussions, we propose the hypotheses $\mathrm{H} 1$.

Hypothesis 1 (H1). EO has a positive association with different innovation drivers.

Hypothesis 1a (H1a). EO has a positive association with SoIn.

Hypothesis $\mathbf{1 b} \mathbf{( H 1 b ) . ~ E O ~ h a s ~ a ~ p o s i t i v e ~ a s s o c i a t i o n ~ w i t h ~ S e I n . ~}$

\subsection{Social Value Orientation (SVO)}

Social value orientation (SVO) is also known as social value, motivational orientation, and social motivation [26]. Past studies define that SVO is a goal or motivation that influences the behaviors of actors whose outcomes are interdependent. Social value orientation (SVO) is classified into four categories: individualistic and competitive as pro-self-values and cooperative and altruistic as pro-social values. A handful of research has attempted to link SVO with behavior in social dilemmas [78-81]. Some researchers clarify the purpose of social value orientation, which is measuring the magnitude of the concern of people have for others [82]. Subsequently, SVO corresponds to how much weight a person attaches to the welfare of others [26,62]. The concept aligned with preferences for specific patterns of consequences for the self and others that underscore a three-category typology of (a) cooperation (i.e., maximizing outcomes for the self and others), (b) individualism (i.e., maximizing outcomes for the self with little or no regard for others' outcomes), and (c) competition (i.e., maximizing relative advantage over others' outcomes) [62]. SVO can be a dispositional source of transformation of a given matrix to affect what behavioral decisions are based on. It is proposed that SVO describes the dispositional weights that individuals attach to their own and another person's outcome, playing an influential role in social dilemmas [83]. Following SVO principles, we assume entrepreneurs bring a positive change to society through different values such as customer value, producer's value, and supply chains' value. There is a high possibility that higher EO results in more innovative changes to solve some social issues in society. Given the above arguments, and drawing on social impact theory that explains how individuals affect and are affected in the social environment [51], we propose H2.

Hypothesis 2 (H2). There is a positive association among the different social drivers.

Hypothesis 2a (H2a). SoIn has a positive association with SoIm.

Hypothesis $\mathbf{2 b} \mathbf{( H 2 b ) . ~ S V O ~ h a s ~ a ~ p o s i t i v e ~ a s s o c i a t i o n ~ w i t h ~ S o I m . ~}$

Hypothesis 2c (H2c). SeIn has a positive association with SoIm.

Hypothesis 2d (H2d). SeIn has a positive association with SVO.

\subsection{Mediators between Entrepreneurial Orientation (EO) and Social Impact (SoIm)}

The literature offers different concepts and definitions of the significant influence of EO on social impact. For example, Kreiser [84] discovers the impact of entrepreneurial orientation (EO) on organizational learning. A research paper by McGee and Peterson [17] studies the impact of entrepreneurial orientation (EO) on venture performance. Cohen et al. [8] examine the association between entrepreneurial orientation and social value creation through social entrepreneurship theories.

We point out that social innovation strives to alleviate social problems. On the other side, firms gain profit with products or services primarily through the support of a different kind of innovation. Social innovation, thus, is an essential tool that favors social conditions. 
Extant literature relates to technological change and innovation. Choi and Williams [7] debate technological efficiency's role in linking EO and company performance. Alegre and Chiva [85] explain the mediation role of innovation performance on the relationship between $\mathrm{EO}$ and organization performance. Wang and Juan [86] suggest that service innovation mediates the relationship between entrepreneurial orientation and consumer satisfaction.

A group of studies including Van et al. [87], Murphy and Ackermann [82], Pletzer et al. [83], and Yan [88] investigates if SVO's dimensions have a significant effect on the different social aspect of social dilemmas. Wei et al. [89] delineate the moderating notion of SVO on the effect of social influence on decision making. Declerck and Bogaert [90] explain social value orientation as individual differences in the way that individuals evaluate and compare results for themselves and others in situations of interdependence. Consequently, concerning early mentioned works, $\mathrm{H} 3$ is presumed.

Hypothesis 3 (H3). Social and service drivers mediate in the relationship between EO and SoIm.

Hypothesis 3a (H3a). SoIn mediates the relationship between EO and SoIm.

Hypothesis $\mathbf{3 b} \mathbf{( H 3 b ) . ~ S V O ~ m e d i a t e s ~ t h e ~ r e l a t i o n s h i p ~ b e t w e e n ~ E O ~ a n d ~ S o I m . ~}$

Hypothesis 3c (H3c). SeIn mediates the relationship between EO and SoIm.

Hypothesis 3d (H3d). SeIn and SVO are multiple serial mediators between EO and SoIm.

\section{Methods}

This study employs structural equation modeling (SEM) to test the proposed hypotheses. It is agreed that SEM is an appropriate confirmatory (e.g., hypothesis-testing) approach when several complex relationships exist [91,92]. Moreover, both SPSS and AMOS 23 are used to analyze the data. Given that our study consists of a large sample, AMOS as a covariance-based SEM is more suitable when theory testing [91]. Descriptive statistics, the test of reliability and validity of measurements, exploratory factor analysis (EFA), and confirmatory factor analysis (CFA) are further discussed in the following sections.

Based on the assumed causal relationships of social and service drivers and their potential social impacts, we validate the measures using structural equation modeling. The following is a mathematical illustration of the analytical process of our research model. Let $\eta$ be the latent of social impact (SoIm, Unobservable), $\xi_{1}$ be entrepreneurial orientation (EO), $\xi_{2}$ be social innovation (SoIn), $\xi_{3}$ be social value orientation (SVO), and $\xi_{4}$ be service innovation (SeIn). We hypothesize social impact, $y$ (Observable), satisfies the following relation:

$$
y=f\left(\xi_{1}, \xi_{2}, \xi_{3}, \xi_{4}\right)+\xi=\eta+\xi
$$

where $\xi$ is an error term with $\sum=\operatorname{Cov}(\xi)$, see Figure 1 . As all the exogenous variables, $\xi_{1}, \xi_{2}, \xi_{3}, \xi_{4}$, and $\xi_{5}$, are hypothesized to lead to the latent, $\eta$, of endogenous variable, $y$, positively, we assume:

$$
\partial \eta / \partial \xi_{i}>0 i=1,2,3,4 .
$$

A linear structural equation is used to represent Equation (1):

$$
Y=\Gamma \xi+\xi
$$

where $\xi=\left[\xi_{1}, \xi_{2}, \xi_{3}, \xi_{4}\right]^{\prime}$ (Figure 1). The endogenous variable, $y$, is observable, but the exogenous variables, $\xi_{1}, \xi_{2}, \xi_{3}$, and $\xi_{4}$, are unobservable. As such, several, said $n_{i}$, of observed items of $x_{i},\left(x_{i j}, j=\right.$ $1 \ldots, n_{i}$ ) are used to measure $\xi_{i}$ for each $i=1,2,3$, and 4 . 
The measurement model for the vector of the exogenous latent variables is:

$$
x=\Lambda_{x} \xi+\delta
$$

where $x=\left[x_{1,1}, x_{1,2}, \ldots, x_{1, n 1}, x_{2,1}, x_{2,2}, \ldots, x_{2, n 2}, x_{2,1}, x_{3,2}, \ldots, x_{3, n 3}, x_{4,1}, x_{4,2}, \ldots, x_{4, n 4}\right]^{\prime}$ and $\xi=\left[\xi_{1}, \xi_{2}, \xi_{3}, \xi_{4}\right]^{\prime}$.

The parameters are estimated using the maximum likelihood estimation as follows:

$$
\text { Max: } M L=\ln |C|-\ln |S|+\operatorname{tr} S C^{-1}-m
$$

where

$\operatorname{tr}=$ trace (sum of the diagonal elements),

$\mathrm{S}=$ covariance matrix of all indices for the latent variables implied by the model,

$\mathrm{C}=$ actual covariance matrix of all indices for the latent variables,

$\ln =$ natural logarithm and

| indicates the determinant of a matrix.

We perform exploratory factor analysis (EFA) and confirmatory factor analysis (CFA) on the hypothesized model (Figure 1), which includes linear structural equations (Equations (1) and (2)) and measurements of the exogenous latent variables (Equation (3)). We also perform correlational analysis to obtain a correlation matrix based on all items for each dimension to use as an input of the path analysis. The CFA allows the examination of the rigorousness of our research model in terms of multicollinearity, reliability, and convergent validity of the scales [93]. The multicollinearity is the extent to which the items are strongly associated with each other and represent a single factor, which is a necessary condition for reliability analysis and construct validation ( $\sqrt{ }$ AVE $>$ Max $\mathrm{r}$ ) [94]. The benefit of using the CFA is to confirm and validate factor loadings obtained from EFA to examine statistical significance. Both the reliability test and correlation analysis can be incorporated into the CFA when assessing the multicollinearity of each factor ( $\sqrt{ }$ AVE $>$ Max $r$ ).

\subsection{Demographic Characteristics}

Table 1 presents the data related to the respondents' profile, such as gender, age, education, job title, and work experience. As shown, the majority of respondents are female $(\mathrm{N}=160,59.3 \%)$, between 45 to 54 years old $(\mathrm{N}=105,38.9 \%)$, and a master's degree is the highest academic education achieved $(\mathrm{N}=128,47.4 \%)$. Participants are mostly general employees $(\mathrm{N}=122,45.2 \%)$. Respondents with more than 22 years of working experience $(\mathrm{N}=140,51.9 \%)$ dominated the sample.

Table 1. Demographic characteristics.

\begin{tabular}{cccc}
\hline Profile & Classifications & Frequency & $\mathbf{( \% )}$ \\
\hline Gender & Male & 110 & 40.7 \\
& Female & 160 & 59.3 \\
& Total & 270 & 100 \\
\hline Age & Under 21 years old & 6 & 2.2 \\
& 21-34 years old & 34 & 12.6 \\
& 35-44 years old & 61 & 22.6 \\
& 45-54 years old & 105 & 38.9 \\
& Above 55 years old & 64 & 23.7 \\
& Total & 270 & 100 \\
\hline Education & Junior/Senior High school & 26 & 9.6 \\
& Bachelor & 96 & 35.6 \\
& Master & 128 & 47.4 \\
& PhD & 20 & 7.4 \\
& Total & 270 & 100 \\
\hline
\end{tabular}


Table 1. Cont.

\begin{tabular}{cccc}
\hline Profile & Classifications & Frequency & $\mathbf{( \% )}$ \\
\hline Job title & Manager & 67 & 24.8 \\
& Senior manager & 18 & 6.7 \\
& CEO/Vice CEO & 16 & 5.9 \\
& SMEs owner & 34 & 12.6 \\
& Engineer/senior technician & 13 & 4.8 \\
& General employee & 122 & 45.2 \\
& Total & 270 & 100 \\
\hline Work experience & Less or one year & 10 & 3.7 \\
& 2-6 years & 23 & 8.5 \\
& 7-11 years & 22 & 8.1 \\
& 12-16 years & 36 & 13.3 \\
& 17-21 years & 39 & 14.4 \\
& Over 22 & 140 & 51.9 \\
& Total & 270 & 100 \\
\hline
\end{tabular}

\subsection{Data Collection}

Data is collected over three months in Taiwan. Following the convenience sampling technique, researchers pass the questionnaires to accessible private sectors via postal mail or email to obtain an appropriate sample size. The purpose of the study relates to entrepreneurial orientation (EO) and social impact (SoIm). Managers, senior managers, CEOs/vice CEOs, SMEs owners, engineers, senior technicians, and employees of private sectors engaged with entrepreneurial activities are participants of this study. Based on the proposed research model, the quantitative SEM method is a suitable approach to test the validity and reliability of the measurement scale. Following sampling principles for SEM [95], we distributed a total of 380 questionnaires. Respondents claim to have work experience in Taiwan. Data collection eventually resulted in $270(75 \%)$ valid and usable data.

\subsection{Measurement and Operationalization of the Constructs}

This study adopts the measurement scales from existing validated sources with slight modifications to fit the current research context. The instrument used includes demographic and construct item sections. We adopted five items from Lumpkin and Dess [13] to measure entrepreneurial orientation (EO). Five items from Moulart et al. $[59,60]$ are employed to measure social innovation (SoIn). The second mediator, social value orientation (SVO), is assessed using four items, adapting from Messick and McClintock [26]. The third mediator service innovation (SeIn) is measured using four items developed from the overview of the definition of social innovation provided by the European Commission [96]. Finally, social impact (SoIm) is assessed using four items borrowed from [97] study. We first interviewed possible participants to select qualified respondents before distributing the questionnaires. Additionally, when preparing the first draft of the instrument, surveyors' observations were considered. Since research items are from existing English sources, we first translated all construct items from English to Mandarin, and later, back-translated to English to ensure the equivalency of items. While pretesting the research instrument, participants verified the clarity of the questions. Thus, the initial content validity of the questionnaire is confirmed.

\section{Results and Findings}

\subsection{Test of Reliability and Validity}

Exploratory factor analysis (EFA) enables researchers to refine measures, evaluating construct validity and also test hypotheses. To get a satisfactory model, we followed a set of general suggestions by Tabachnick and Fidell (2001). Accordingly, the Kaiser-Meyer-Olkin measure of sampling adequacy 
(KMO) must be greater than 0.6 , communality values must be greater than 0.5 , and eigenvalues must be greater than 1 [98].

Table 2 presents the results of factor analysis, instrument validity, and reliability. All factor loadings are above 0.5. The Kaiser-Meyer-Olkin (KMO) Test measures the suitability of the data for factor analysis. Kaiser [99] introduced a measure of sampling adequacy (MSA); later, Kaiser and Rice [100] modified the MSA. The Kaiser-Meyer-Olkin (KMO) statistic varies from 0 to 1 and indicates the predictability of each variable in a set by the other variables without error. The test measures sampling adequacy for each variable in the model and the complete model. KMO for the data in this study is 0.961 , which is higher than 0.95 , indicating the sample is highly adequate. Thus, the validity of the instrument for this study passed Bartlett's Test of Sphericity. We use the principal component analysis extraction method and Varimax rotation to implement EFA. All factors have an eigenvalue of 1 or higher. As shown in Table 2, the reliability coefficient of each factor and the whole instrument is higher than the acceptable level of $(\alpha \geq 0.7)$. In short, the results shown in Table 2 indicate that all factors are valid and reliable. Thus, we can further conduct additional statistical analysis, as discussed in the next subsections.

Table 2. Factor analysis, scale validity, and reliability.

\begin{tabular}{|c|c|c|c|c|c|c|c|}
\hline \multirow{2}{*}{ Variables } & \multirow{2}{*}{ Items } & \multirow{2}{*}{ Mean } & \multirow{2}{*}{ SD } & \multirow{2}{*}{$\%$ of Variance } & \multicolumn{2}{|c|}{ Loadings } & \multirow{2}{*}{ Cronbach's Alpha } \\
\hline & & & & & EFA & CFA & \\
\hline \multirow{5}{*}{ Entrepreneurial orientation (EO) } & EO1 & 4.58 & 0.776 & \multirow{5}{*}{57.723} & 0.865 & 0.881 & \multirow{5}{*}{0.838} \\
\hline & $\mathrm{EO} 2$ & 4.59 & 0.719 & & 0.836 & 0.814 & \\
\hline & $\mathrm{EO} 3$ & 4.53 & 0.769 & & 0.875 & 0.865 & \\
\hline & $\mathrm{EO} 4$ & 4.47 & 0.789 & & 0.781 & 0.720 & \\
\hline & EO 5 & 4.23 & 0.932 & & 0.745 & 0.650 & \\
\hline \multirow{5}{*}{ Social innovation (SoIn) } & SoIn 1 & 4.25 & 0.825 & \multirow{5}{*}{68.280} & 0.810 & 0.800 & \multirow{5}{*}{0.922} \\
\hline & SoIn 2 & 4.24 & 0.861 & & 0.825 & 0.798 & \\
\hline & SoIn 3 & 4.23 & 0.856 & & 0.872 & 0.862 & \\
\hline & SoIn 4 & 4.21 & 0.838 & & 0.838 & 0.807 & \\
\hline & SoIn 5 & 4.09 & 0.881 & & 0.833 & 0.781 & \\
\hline \multirow{4}{*}{ Social value orientation (SVO) } & SVO 1 & 3.99 & 0.954 & \multirow{4}{*}{69.270} & 0.804 & 0.795 & \multirow{4}{*}{0.802} \\
\hline & SVO 2 & 4.04 & 0.920 & & 0.719 & 0.599 & \\
\hline & SVO 3 & 3.82 & 0.917 & & 0.788 & 0.649 & \\
\hline & SVO 4 & 4.08 & 0.909 & & 0.857 & 0.839 & \\
\hline \multirow{4}{*}{ Service innovation (SeIn) } & SeIn 1 & 4.53 & 0.709 & \multirow{4}{*}{78.944} & 0.853 & 0.801 & \multirow{4}{*}{0.911} \\
\hline & SeIn 2 & 4.44 & 0.801 & & 0.919 & 0.880 & \\
\hline & SeIn 3 & 4.57 & 0.781 & & 0.896 & 0.866 & \\
\hline & SeIn 4 & 4.46 & 0.797 & & 0.884 & 0.853 & \\
\hline \multirow{4}{*}{ Social impact (SoIm) } & SoIm 1 & 4.25 & 0.788 & \multirow{4}{*}{70.423} & 0.823 & 0.784 & \multirow{4}{*}{0.911} \\
\hline & SoIm 2 & 4.11 & 0.891 & & 0.848 & 0.775 & \\
\hline & SoIm 3 & 4.10 & 0.873 & & 0.841 & 0.737 & \\
\hline & SoIm 4 & 4.34 & 0.846 & & 0.819 & 0.790 & \\
\hline \multirow{2}{*}{ Instrument Total } & KMO & \multirow{2}{*}{\multicolumn{5}{|c|}{$\begin{array}{l}0.961 \\
0.000\end{array}$}} & \multirow{2}{*}{0.962} \\
\hline & $p$-value & & & & & & \\
\hline
\end{tabular}

Note: Item details are as follows: EO1: Autonomy can enhance her active engagement for the job. EO2: Innovativeness can enhance performance in the job. EO3: Initiative can enhance her performance in an innovative event. EO4: Competitive capacity can enhance the performance in the job. EO5: Risk-taking orientation can enhance her willingness in an uncertain environment. SoIn1: Social innovation is the practical development of new products, services, and solutions model, which meets social needs. SoIn2: New solutions portfolio (new product, new service, and new processes) can achieve the capacity of management. SoIn3: Social innovation can advance the quality of life of individuals and communities through a new delivery service. SoIn4: Innovative activities can be diffused through an organization's promotion. SoIn5: Social innovation contributes to improving the workforce of an individual. SVO1: Prosocial personality can enhance the value of society. SVO2: Individualistic personality will influence the organization's outcomes. SVO3: Competitive personality can enhance the organization's outcomes. SVO4: Altruistic personality can enhance the value of society. SeIn1: A good service concept consists of knowledge that can achieve one complete services system. SeIn2: By using a good client interface, firms can enhance their performance and service quality? (For example, customers do not need to come to the bank; they can use it). SeIn3: A good service delivery system can enhance the efficiency of business operations. SeIn4: Technological right choice can enhance the performance of service systems. SoIm1: When managers have high entrepreneurial orientation, they can enhance the value of society. SoIm2: A manager can enhance the value of society through new social collaborations. SoIm3: A new business model can enhance the welfare of society. SoIm4: The manager's intelligence can enhance the value of society. 


\subsection{Confirmatory Factor Analysis (CFA)}

The goodness of fit of the model was evaluated and compared with the suggested criteria by the ratio of chi-square to degrees of freedom $\left(\chi^{2} / \mathrm{df}\right)<3$, goodness-of-fit index $(\mathrm{GFI})>0.8$, the root mean square error of approximation (RMSEA) $\leq 0.08$, and the comparative fit index (CFI) $>0.9$ indices (Brown, 2015). The measurement model of CFA in this model shows the fit index for the structural model, which indicated a good fit $\left(\chi^{2} / \mathrm{df}=1.939 ;\right.$ RMSEA $=0.059 ; \mathrm{CFI}=0.956$; GFI $\left.=0.884\right)$. Therefore, the results of the model fit for CFA and the proposed model are satisfactory (Table 3 ).

Table 3. Model fit indices of the measurement model.

\begin{tabular}{cccc}
\hline Indices & Criteria & Model & CFA \\
\hline$\chi^{2} / \mathrm{df}$ & $<3$ & 2.373 & 1.93 \\
GFI & $>0.8$ & 0.86 & 0.88 \\
CFI & $>0.9$ & 0.93 & 0.95 \\
RMSEA & $\leq 0.08$ & 0.07 & 0.06 \\
\hline
\end{tabular}

\subsection{Composite Reliability, Convergent and Discriminant Validity}

In this study, composite reliability (CR) is used to reveal the reliability and internal consistency of the instrument. Similarly, convergent and discriminant validity are employed to test each construct's validity [101]. Thus, scale reliability is assessed in different ways using CR and AVE values that should be, respectively, greater than 0.7 and 0.5 [101]. AVE refers to the average percent of variation explained among the items [102]. We evaluate discriminant validity by comparing the square root of AVE value with the correlation between constructs. Consequently, with AVE $>0.5, \mathrm{MSV}<\mathrm{AVE}, \mathrm{CR}>\mathrm{AVE}$, $\sqrt{ } \mathrm{AVE}>\operatorname{Max} \mathrm{r}$ (maximum interrelated correlation) reliability, and validity of the scale and constructs of the research model is supported. Table 4 summarizes the results of validity and reliability.

Table 4. Test of composite reliability, convergent validity, and discriminant validity.

\begin{tabular}{cccccccccc}
\hline & CR & AVE & MSV & Max r & EO & SoIn & EO & SeIn & SoIm \\
\hline SoIn & 0.905 & 0.656 & 0.578 & 0.760 & $\mathbf{0 . 8 1 0}$ & & & & \\
EO & 0.892 & 0.625 & 0.549 & 0.741 & 0.626 & $\mathbf{0 . 7 9 1}$ & & & \\
SeIn & 0.912 & 0.723 & 0.588 & 0.767 & 0.760 & 0.741 & $\mathbf{0 . 8 5 0}$ & & \\
SoIm & 0.855 & 0.596 & 0.588 & 0.767 & 0.756 & 0.635 & 0.767 & $\mathbf{0 . 7 7 2}$ & \\
SVO & 0.807 & 0.516 & 0.468 & 0.684 & 0.664 & 0.622 & 0.674 & 0.684 & $\mathbf{0 . 7 1 8}$ \\
\hline \multicolumn{7}{c}{ Note: CR $>0.7 ;$ AVE $>0.5 ;$ MSV $<$ AVE; $\sqrt{ }$ AVE $>$ Max r, $\sqrt{ }$ AVE is boldface diagonal. }
\end{tabular}

\subsection{Test of Hypotheses and Mediations}

As explained, to test the proposed model, researchers employ structural equation modeling (SEM). In conclusion, all the direct effects are positively significant. Therefore, the first two hypotheses ( $\mathrm{H} 1$ and $\mathrm{H} 2$ ) and sub-hypotheses (H1a, H1b, H2a, H2b, H2c, and H2d) are accepted. Table 5 recapitulates the results of hypotheses testing.

Table 6 presents the result of the mediation hypotheses for the research model. The results of mediation analysis, using 3000 re-samplings' bootstrapping, support the mediation hypothesis $\mathrm{H} 3$ and all sub-hypotheses (H3a, H3b, H3c, and H3d). Thus, according to H3a, SoIn partially mediates the relationship between EO and SoIm. Following H3b, the partial mediation of SVO on the relationship between EO and SoIm is revealed. Regarding H3c, findings show that SeIn can fully mediate the link between EO and SoIm. Concerning H3d, although the direct effect of the defined path is not significant, double mediation of SeIn and SVO are proved. Finally, SVO is a partial mediator on the association between EO and SoIm. 
Table 5. Results of the hypotheses (standardized regression weights).

\begin{tabular}{|c|c|c|c|c|}
\hline Hypothesis & Paths & Estimate & Statement of Hypothesis & Results \\
\hline H1a & $\mathrm{EO} \rightarrow$ SoIn & $0.74^{* * *}$ & EO has positive association with SoIn & Supported \\
\hline $\mathrm{H} 1 \mathrm{~b}$ & $\mathrm{EO} \rightarrow$ SeIn & $0.86^{* * *}$ & EO has positive association with SeIn & Supported \\
\hline $\mathrm{H} 2 \mathrm{a}$ & SoIn $\rightarrow$ SoIm & $0.39 * * *$ & SoIn has positive association with SoIm & Supported \\
\hline $\mathrm{H} 2 \mathrm{~b}$ & $\mathrm{SVO} \rightarrow$ SoIm & $0.32 * * *$ & SVO has positive association with SoIm & Supported \\
\hline $\mathrm{H} 2 \mathrm{c}$ & SeIn $\rightarrow$ SoIm & $0.34^{* * *}$ & SeIn has positive association with SoIm & Supported \\
\hline $\mathrm{H} 2 \mathrm{~d}$ & SeIn $\rightarrow$ SVO & $0.79 * * *$ & SeIn has positive association with SVO & Supported \\
\hline
\end{tabular}

Table 6. Results of the mediation hypotheses (standardized regression weights).

\begin{tabular}{|c|c|c|c|c|c|}
\hline & Paths & Indirect (ab) & Direct $\left(c^{\prime}\right)$ & Total (c) & Mediation \\
\hline Н3а & $\mathrm{EO} \rightarrow$ SoIn $\rightarrow$ SoIm & $0.46^{* * *}$ & $0.25 *$ & $0.71 * * *$ & Partial mediation \\
\hline $\mathrm{H} 3 \mathrm{~b}$ & $\mathrm{EO} \rightarrow \mathrm{SVO} \rightarrow \mathrm{SoIm}$ & $0.44^{* * *}$ & $0.27 *$ & $0.71^{* * *}$ & Partial mediation \\
\hline $\mathrm{H} 3 \mathrm{c}$ & $\mathrm{EO} \rightarrow$ SeIn $\rightarrow$ SoIm & $0.69 * *$ & NS & $0.71^{* * *}$ & Full mediation \\
\hline $\mathrm{H} 3 \mathrm{~d}$ & $\mathrm{EO} \rightarrow \mathrm{SeIn} \rightarrow \mathrm{SVO} \rightarrow$ SoIm & $0.71 * * *$ & NS & $0.71^{* * *}$ & Full mediation \\
\hline
\end{tabular}

\section{Discussion}

Although extant studies documented the critical role of entrepreneurial orientation (EO) in affecting the performance of organizations and societies, understanding the EO as a fundamental element that can influence and predict social events is not well studied. This paper extends the existing entrepreneurship and innovation theory from the perspective of social factors. The main attempt is to structure a new research framework to investigate the influence of entrepreneurial orientation (EO) on generating social impact by considering social factors such as social innovation, service innovation, and social value. Evidence shows that in EO literature, innovativeness, proactiveness, and risk-taking are among the most important constructs to define firm performance and to let managers make a strategic decision. However, previous studies often assess EO with firm-level performance. This study attempts to relate entrepreneurial orientation (EO) as an antecedent of sustainable social impact. Relying on EO literature that applies not only to firm-level behavior, but also to the process of entrepreneurial development at the societal level of countries, researchers have developed several hypotheses. In conclusion, the findings indicate that the suggested constructs of $\mathrm{EO}$ are an influential element that can create social impact. This is primarily through other factors, namely SoIn, SeIn, and SVO, that fully or partially mediate the proposed relationship.

According to the results exhibited in Table 5, H1a is supported, which means that EO has a positive association with SoIn ( $\beta=0.74, p<0.001$ ). Thus, in Taiwan, entrepreneurial orientation (EO) is shown to have a significant positive influence on social innovativeness (SoIn). We concluded that in Taiwan, social innovation (SoIn) is directly affected by the entrepreneurial characteristics of managers, CEOs, and other individual entrepreneurs. This point highlights the vital role of entrepreneurial characters in creating social innovation. In this regard, our result is consistent with the previous study conducted by Pérez-Luño et al. [36], explaining how entrepreneurial orientation promotes innovation generation in Spain. Moreover, our findings are in line with a new scientific survey that shows entrepreneurial orientation fosters innovation in companies at individual and firm-level [103]. $\mathrm{H} 1 \mathrm{~b}$ states that EO has a positive association with SeIn. Our findings illustrated in Table 5 claim that there is a positive significant relationship between EO and SeIn $(\beta=0.86, p<0.001)$. Therefore, $\mathrm{H} 1 \mathrm{~b}$ is also accepted. According to Wang and Juan [86], entrepreneurial orientation (EO) is related to service innovation performance, which stresses the effectiveness of the entrepreneurial orientation (EO) mechanism on consumer response. In addition, the new technology also can promote the development of entrepreneurial activities that eventually may result in economic growth [104]. 
Given that new technologies are part of innovation, it is highly possible that entrepreneurial orientation (EO) positively affects service innovation.

H2a states that SoIn has a positive association with SoIm. The results of SEM analyses indicate that, for the given model, SoIn positively and significantly influences SoIm $(\beta=0.39, p<0.001)$. H2a is, therefore, accepted. This result is also consistent with prior scholars' findings [65,105] discussing social innovations and their impact on the society and environment. In this regard, our findings corroborate the scientific work of Wittmayer et al. [106] underlining the transformative potentials of social innovation in generating sustainable social impact.

$\mathrm{H} 2 \mathrm{~b}$ proposes that social value orientation (SVO) has a positive association with social impact (SoIm). Subsequently, statistical analysis reveals a significant positive impact of SVO on social impact ( $\beta=0.32, p<0.001$ ). Our result confirms the past research findings are addressing the significant role of social value orientation (SVO) in solving social dilemmas [78].

H2c hypothesizes that SeIn has a positive association with SoIm. The statistical results of current path analyses (Table 5) indicate that SeIn significantly and positively influences SoIm $(\beta=0.34$, $p<0.001)$. Thus, $\mathrm{H} 2 \mathrm{c}$ is supported. H2d proposes that SeIn has a positive association with SVO. As the result shows, there is a significant positive relationship between SeIn and SVO ( $\beta=0.79$, $p<0.001)$. H3a hypothesizes that SoIn mediates the relationship between EO and SoIm. The results of the mediation hypotheses reveal that SoIn partially mediates the relationship between EO and SoIm. Our finding is in line with the definition of social innovation, a novel solution to a social problem $[107,108]$. Existing organizational research explains that EO is one of the fundamental needs representing innovative capability [86,109]. The link between EO and social impact could be more efficient, while social innovation intervenes in the process. Although one stream of research attempts to show the effectiveness of innovation in diverse areas [52,110], few studies have investigated the mediating role of social innovation on the relationship between entrepreneurial orientation and social impact.

$\mathrm{H} 3 \mathrm{~b}$ proposes that SVO mediates the relationship between EO and SoIm. SVO fully mediates the relationship between $\mathrm{EO}$ and SoIm. Thus, $\mathrm{H} 3 \mathrm{~b}$ also received support. As both direct and indirect effects are found significant, the partial mediation of SVO on the relationship between EO and SoIm is revealed.

H3d states that SeIn and SVO are multiple serial mediators between EO and SoIm. According to statistical results achieved, SeIn and SVO act as multiple serial mediators between EO and SoIn. First, researchers test each mediator as a separate single variable to check if each SeIn and SVO can fully mediate the defined relationship. Although the direct effect of the path is not statistically significant, SeIn and SVO perform as full mediating variables. Therefore, H3d is accepted.

\section{Conclusions and Implications}

Every country is committed to sustainable development, but it faces many social dilemmas. These social problems include hunger, poverty, water scarcity, crime, drug use, cancer, plague, lack of natural resources, ecosystems, and disasters. The knowledge and skills of entrepreneurs are crucial to address these issues. This study will help to strengthen effective collaboration between government decision-makers and entrepreneurs, and their cross-disciplinary cooperation to find practical solutions to social and environmental problems.

Entrepreneurial orientation is a crucial variable that nurtures individual and organizational growth, which in turn affects the sustainable development of the economy and societies $[42,103]$. Therefore, based on previous studies and considering a new research framework, this current paper underscores the importance of entrepreneurial orientation concerning social drivers. Entrepreneurial orientation (EO), representing the ability to promote performances through innovative attitude, risk-taking behavior, aggressiveness, autonomy, and competitive energy [9], plays an essential role in predicting the social development of societies if other defined social drivers exist in the system. From another viewpoint, it can be concluded that individuals with specific abilities can positively 
influence service innovation. Moreover, a sustainable entrepreneurial climate in firms positively affects service innovation alternatives to enhance the efficiency of business operations or accelerate the recognition of the right technology choices to enable the managers to increase the performance of service systems.

Research findings give a new direction for policymakers to foster entrepreneurship culture and generate sustainable social impact. Managers and decision-makers can use the results to improve the progress of entrepreneurial activities. Entrepreneurial orientation leads to long-term social impact through the effective implementation of social innovation. Therefore, promoting characteristics such as autonomy, innovativeness, initiative, competitive capacity, and risk-taking in the organization in employees can elevate an entrepreneurial ecosystem that creates social impact.

Effective entrepreneurial orientation and innovative methods need to accelerate social innovation. This study drew a way to create sustainable social impact through social innovation, service innovation, and social value. International organizations strive to work for sustainable development goals. From an organizational perspective, in order to generate social impact, companies can consider recruiting managers with a more robust entrepreneurial profile. To enhance positive social impact, providing suitable training and educational courses for employees will provide opportunities for the growth of EO. Practitioners should notice that successful change and innovation processes are expected to occur more frequently when a high level of EO is experienced at an individual and firm-level. The interaction between EO at the personal and organizational levels can better perform as a determinant of sustainable change. From a theoretical perspective, our study expands past research in different ways. EO is found as an essential element for creating long-term social impact. EO plays an essential role in building innovation and competitive advantage that directly and positively influence how individual and organization's actions impact on surrounding communities. We admit that other contextual factors in the form of values exert positive force on this association.

Notably, research findings contribute to entrepreneurial theory and social sustainability literature by considering the effectiveness of social innovation, service innovation, and social value orientation at both individual and firm-level. Notably, defined factors as mediators that have never been studied before are recognized as potential indicators of social impact. As a result, the existence of SoIn, SeIn, and SVO positively and significantly influences the main link between EO and SoIm. Therefore, to stimulate the process of creating social impact, the mentioned variables could be used. Findings also suggest that social innovation is required in society to achieve long-term social impact. While the mediating role of social innovation, service innovation, and social value orientation is revealed, managers are advised to take advantage of these social values. Relevant policy recommendations are proposed to provide a theoretical basis for the government to promote long-term, sustainable social impact and provide practical suggestions for the social development of developing and emerging countries.

This study has some limitations that give directions for future works. First, our results are restricted to Taiwan. Taiwan is among the successful developed countries in Asia. It would be more interesting to conduct a similar study in other countries in or out of the region. Thus, we encourage future research to collect data from other national settings. Thus, the findings of the current study can be a base for future comparison studies. Other factors related to cultural background may also get involved to expand the model. Another possible limitation of the study is the fact that we collect data from companies with a wide variety of disciplines; further research is advised to select a specific industry to provide more specific conclusions.

Author Contributions: Conceptualization, P.A. and M.M.; Data curation, P.A.; Formal analysis, A.D.; Funding acquisition, T.M., G.-O.L. and M.M.; Methodology, A.D. and M.M.; Project administration, M.M.; Supervision, M.M.; Writing—original draft, P.A. and M.M.; Writing—review \& editing, A.D., M.M., P.A., and T.M. All authors have read and agreed to the published version of the manuscript.

Funding: This research received no external funding.

Conflicts of Interest: The authors declare no conflict of interest. 


\section{References}

1. Bellé, N. Leading to make a difference: A field experiment on the performance effects of transformational leadership, perceived social impact, and public service motivation. J. Public Adm. Res. Theory 2014, 24, 109-136. [CrossRef]

2. Castanheira, F. Perceived social impact, social worth, and job performance: Mediation by motivation. J. Organ. Behav. 2016, 37, 789-803. [CrossRef]

3. Fowler, E.A.; Coffey, B.S.; Dixon-Fowler, H.R. Transforming good intentions into social impact: A case on the creation and evolution of a social enterprise. J. Bus. Ethics 2019, 159, 665-678. [CrossRef]

4. Rawhouser, H.; Cummings, M.; Newbert, S.L. Social impact measurement: Current approaches and future directions for social entrepreneurship research. Entrep. Theory Pract. 2019, 43, 82-115. [CrossRef]

5. Moslehpour, M.; Altantsetseg, P.; Mou, W.; Wong, W.-K. Organizational Climate and Work Style: The Missing Links for Sustainability of Leadership and Satisfied Employees. Sustainability 2019, 11, 125. [CrossRef]

6. Kelley, D.; Singer, S.; Herrington, M. Global entrepreneurship monitor. In Global Report; Global Entrepreneurship Research Association, London Business School: London, UK, 2016.

7. Choi, S.B.; Williams, C. Entrepreneurial orientation and performance: Mediating effects of technology and marketing action across industry types. Ind. Innov. 2016, 23, 673-693. [CrossRef]

8. Cohen, D.G.; Gauthier, J.; Meyer, C. Entrepreneurial Orientation and Social Value Creation. In Academy of Management Proceedings; Academy of Management: Briarcliff Manor, NY, USA, 2019; p. 11456. [CrossRef]

9. Covin, J.G.; Wales, W.J. Crafting High-Impact Entrepreneurial Orientation Research: Some Suggested Guidelines; SAGE Publications Sage CA: Los Angeles, CA, USA, 2019. [CrossRef]

10. Covin, J.G.; Slevin, D.P. The influence of organization structure on the utility of an entrepreneurial top management style. J. Manag. Stud. 1988, 25, 217-234. [CrossRef]

11. Semrau, T.; Ambos, T.; Kraus, S. Entrepreneurial orientation and SME performance across societal cultures: An international study. J. Bus. Res. 2016, 69, 1928-1932. [CrossRef]

12. Kraus, S.; Rigtering, J.C.; Hughes, M.; Hosman, V. Entrepreneurial orientation and the business performance of SMEs: A quantitative study from the Netherlands. Rev. Manag. Sci. 2012, 6, 161-182. [CrossRef]

13. Lumpkin, G.T.; Dess, G.G. Clarifying the entrepreneurial orientation construct and linking it to performance. Acad. Manag. Rev. 1996, 21, 135-172. [CrossRef]

14. Aparicio, S.; Urbano, D.; Audretsch, D. Institutional factors, opportunity entrepreneurship and economic growth: Panel data evidence. Technol. Forecast. Soc. Chang. 2016, 102, 45-61. [CrossRef]

15. Pansera, M.; Sarkar, S. Crafting sustainable development solutions: Frugal innovations of grassroots entrepreneurs. Sustainability 2016, 8, 51. [CrossRef]

16. Richard, O.C.; Barnett, T.; Dwyer, S.; Chadwick, K. Cultural diversity in management, firm performance, and the moderating role of entrepreneurial orientation dimensions. Acad. Manag. J. 2004, 47, $255-266$. [CrossRef]

17. McGee, J.E.; Peterson, M. The long-term impact of entrepreneurial self-efficacy and entrepreneurial orientation on venture performance. J. Small Bus. Manag. 2019, 57, 720-737. [CrossRef]

18. Bode, C.; Singh, J.; Rogan, M. Corporate social initiatives and employee retention. Organ. Sci. 2015, 26, 1702-1720. [CrossRef]

19. Bowling, A.; Gabriel, Z.; Dykes, J.; Dowding, L.M.; Evans, O.; Fleissig, A.; Banister, D.; Sutton, S. Let's ask them: A national survey of definitions of quality of life and its enhancement among people aged 65 and over. Int. J. Aging Hum. Dev. 2003, 56, 269-306. [CrossRef] [PubMed]

20. Dawson, P.; Daniel, L. Understanding social innovation: A provisional framework. Int. J. Technol. Manag. 2010, 51, 9-21. [CrossRef]

21. Buchegger, B.; Ornetzeder, M. Social innovations on the way to sustainable development. In Proceedings of the ESEE Conference Proceeding, Vienna, Austria, 3-6 May 2000.

22. Hämäläinen, T.J. Social innovation, structural adjustment and economic performance. In Social Innovations, Institutional Change and Economic Performance: Making Sense of Structural Adjustment Processes in Industrial Sectors, Regions and Societies; Edward Elgar Publishers: Cheltenham, UK, 2007; pp. 11-51. [CrossRef]

23. Lee, L. Institutions and ideas in social change. Am. J. Econ. Sociol. 1959, 18, 127-138. [CrossRef]

24. Hargrave, T.J.; Van de Ven, A.H. A collective action model of institutional innovation. Acad. Manag. Rev. 2006, 31, 864-888. [CrossRef] 
25. Moslehpour, M.; Pham, V.; Wong, W.-K.; Bilgiçli, İ. E-purchase intention of Taiwanese consumers: Sustainable mediation of perceived usefulness and perceived ease of use. Sustainability 2018, 10, 234. [CrossRef]

26. Messick, D.M.; McClintock, C.G. Motivational bases of choice in experimental games. J. Exp. Soc. Psychol. 1968, 4, 1-25. [CrossRef]

27. Kuhlman, D.M.; Marshello, A.F. Individual differences in game motivation as moderators of preprogrammed strategy effects in prisoner's dilemma. JPSP 1975, 32, 922. [CrossRef]

28. Den Hertog, P.; Bilderbeek, R. Conceptualising service innovation and service innovation patterns. In Research Programme on Innovation in Services (SIID) for the Ministry of Economic Affairs; Dialogic: Utrecht, The Netherlands, 1999. [CrossRef]

29. Bedeski, R.E.; Andersen, A.; Darmosumarto, S. Small Arms Trade and Proliferation in East Asia: Southeast Asia and the Russian Far East; Working Paper No 24; Institute of International Relations, University of British Columbia: Vancouver, BC, Canada, 1998.

30. Hauge, J. Industrial policy in the era of global value chains: Towards a developmentalist framework drawing on the industrialisation experiences of South Korea and Taiwan. World Econ. 2020. [CrossRef]

31. Messersmith, J.G.; Wales, W.J. Entrepreneurial orientation and performance in young firms: The role of human resource management. Int. Small Bus. J. 2013, 31, 115-136. [CrossRef]

32. Rodrigo-Alarcón, J.; García-Villaverde, P.M.; Ruiz-Ortega, M.J.; Parra-Requena, G. From social capital to entrepreneurial orientation: The mediating role of dynamic capabilities. Eur. Manag. J. 2018, 36, 195-209. [CrossRef]

33. Stam, W.; Elfring, T. Entrepreneurial orientation and new venture performance: The moderating role of intra-and extraindustry social capital. Acad. Manag. J. 2008, 51, 97-111. [CrossRef]

34. Kádeková, Z.; Savov, R.; Košičiarová, I.; Valaskova, K. CSR Activities and Their Impact on Brand Value in Food Enterprises in Slovakia Based on Foreign Participation. Sustainability 2020, 12, 4856. [CrossRef]

35. Karimi, S.; Biemans, H.J.; Naderi Mahdei, K.; Lans, T.; Chizari, M.; Mulder, M. Testing the relationship between personality characteristics, contextual factors and entrepreneurial intentions in a developing country. Int. J. Psychol. 2017, 52, 227-240. [CrossRef]

36. Pérez-Luño, A.; Wiklund, J.; Cabrera, R.V. The dual nature of innovative activity: How entrepreneurial orientation influences innovation generation and adoption. J. Bus. Ventur. 2011, 26, 555-571. [CrossRef]

37. Kreiser, P.M.; Marino, L.D.; Kuratko, D.F.; Weaver, K.M. Disaggregating entrepreneurial orientation: The non-linear impact of innovativeness, proactiveness and risk-taking on SME performance. Small Bus. Econ. 2013, 40, 273-291. [CrossRef]

38. Diabate, A.; Sibiri, H.; Wang, L.; Yu, L. Assessing SMEs' Sustainable Growth through Entrepreneurs' Ability and Entrepreneurial Orientation: An Insight into SMEs in Côte d'Ivoire. Sustainability 2019, 11, 7149. [CrossRef]

39. Shan, P.; Song, M.; Ju, X. Entrepreneurial orientation and performance: Is innovation speed a missing link? J. Bus. Res. 2016, 69, 683-690. [CrossRef]

40. Ok, C.; Ahn, H.S. How Does Entrepreneurial Orientation Influence the Sustainable Growth of SMEs? The Role of Relative Performance. Sustainability 2019, 11, 5178. [CrossRef]

41. Manzano-García, G.; Ayala-Calvo, J.-C. Entrepreneurial Orientation: Its Relationship with the Entrepreneur's Subjective Success in SMEs. Sustainability 2020, 12, 4547. [CrossRef]

42. Butkouskaya, V.; Llonch-Andreu, J.; Alarcón-del-Amo, M.-d.-C. Entrepreneurial Orientation (EO), Integrated Marketing Communications (IMC), and Performance in Small and Medium-Sized Enterprises (SMEs): Gender Gap and Inter-Country Context. Sustainability 2020, 12, 7159. [CrossRef]

43. Engelen, A.; Gupta, V.; Strenger, L.; Brettel, M. Entrepreneurial orientation, firm performance, and the moderating role of transformational leadership behaviors. J. Manag. 2015, 41, 1069-1097. [CrossRef]

44. Markin, E.; Gupta, V.K.; Pierce, C.A.; Covin, J. Entrepreneurial Orientation, Firm-Performance, and the Role of National Culture. In Academy of Management Proceedings; Academy of Management: Briarcliff Manor, NY, USA, 2019; p. 11247. [CrossRef]

45. Poudel, K.P.; Carter, R.; Lonial, S. The Impact of Entrepreneurial Orientation, Technological Capability, and Consumer Attitude on Firm Performance: A Multi-Theory Perspective. J. Small Bus. Manag. 2019, 57, 268-295. [CrossRef]

46. Stevenson, H.H.; Jarillo, J.C. A paradigm of entrepreneurship: Entrepreneurial management. In Entrepreneurship; Springer: Berlin/Heldelberg, Germany, 2007; pp. 155-170. [CrossRef] 
47. Covin, J.G.; Slevin, D.P. A conceptual model of entrepreneurship as firm behavior. Entrep. Theory Pract. 1991, 16, 7-26. [CrossRef]

48. Ireland, R.D.; Covin, J.G.; Kuratko, D.F. Conceptualizing corporate entrepreneurship strategy. Entrep. Theory Pract. 2009, 33, 19-46. [CrossRef]

49. Lee, S.M.; Lim, S. Entrepreneurial orientation and the performance of service business. Serv. Bus. $2009,3,1$. [CrossRef]

50. Moss, T.W.; Short, J.C.; Payne, G.T.; Lumpkin, G. Dual identities in social ventures: An exploratory study. Entrep. Theory Pract. 2011, 35, 805-830. [CrossRef]

51. Latané, B.; Wolf, S. The social impact of majorities and minorities. Psychol. Rev. 1981, 88, 438. [CrossRef]

52. Bulut, C.; Eren, H.; Halac, D.S. Social innovation and psychometric analysis. Procedia-Soc. Behav. Sci. 2013, 82, 122-130. [CrossRef]

53. Avelino, F.; Wittmayer, J.M.; Pel, B.; Weaver, P.; Dumitru, A.; Haxeltine, A.; Kemp, R.; Jørgensen, M.S.; Bauler, T.; Ruijsink, S. Transformative social innovation and (dis) empowerment. Technol. Forecast. Soc. Chang. 2019, 145, 195-206. [CrossRef]

54. Schröder, A.; Krüger, D. Social innovation: Integrating learning and technological innovation. Sustainibility 2019, 11, 1070. [CrossRef]

55. Romero-Rodríguez, J.-M.; Ramírez-Montoya, M.-S.; Aznar-Díaz, I.; Hinojo-Lucena, F.-J. Social appropriation of knowledge as a key factor for local development and open innovation: A systematic review. J. Open Innov. Technol. Mark. Complex. 2020, 6, 44. [CrossRef]

56. Lisetchi, M.; Brancu, L. The entrepreneurship concept as a subject of social innovation. Procedia-Soc. Behav. Sci. 2014, 124, 87-92. [CrossRef]

57. Castro-Arce, K.; Vanclay, F. Transformative social innovation for sustainable rural development: An analytical framework to assist community-based initiatives. J. Rural Stud. 2020, 74, 45-54. [CrossRef]

58. Milbergs, E.; Vonortas, N. Innovation Metrics: Measurement to Insight; Center for Accelerating Innovation and George Washington University, National Innovation Initiative 21st Century Working Group: Washington, DC, USA, 2004; p. 22. [CrossRef]

59. Moulaert, F.; MacCallum, D.; Mehmood, A.; Hamdouch, A. General introduction: The return of social innovation as a scientific concept and a social practice. Int. Handb. Soc. Innov. Collect. Action Soc. Learn. Transdiscipl. Res. 2013, 1, 1-6. [CrossRef]

60. Moulaert, F.; Martinelli, F.; Swyngedouw, E.; Gonzalez, S. Towards alternative model(s) of local innovation. Urban Stud. 2005, 42, 1969-1990. [CrossRef]

61. Howaldt, J.; Schwarz, M. Social Innovation: Concepts, Research Fields and International Trends Studies for Innovation in a Modern Working Environment-International Monitoring. Int. Monit. 2010, 5. [CrossRef]

62. Murray, R.; Caulier-Grice, J.; Mulgan, G. The Open Book of Social Innovation; National Endowment for Science, Technology and the Art London: London, UK, 2010.

63. Baturina, D.; Bežovan, G. Social innovation impact-review no. 9. In Seventh Framework Programme (Grant Agreement 613034); Third Sector Impact; European Union: Brussels, Belgium, 2015.

64. Krlev, G.; Bund, E.; Mildenberger, G. Measuring what matters-Indicators of social innovativeness on the national level. Inf. Syst. Manag. 2014, 31, 200-224. [CrossRef]

65. Cajaiba-Santana, G. Social innovation: Moving the field forward. A conceptual framework. Technol. Forecast. Soc. Chang. 2014, 82, 42-51. [CrossRef]

66. Gallouj, F.; Rubalcaba, L.; Toivonen, M.; Windrum, P. Understanding social innovation in services industries. Ind. Innov. 2018, 25, 551-569. [CrossRef]

67. Witell, L.; Snyder, H.; Gustafsson, A.; Fombelle, P.; Kristensson, P. Defining service innovation: A review and synthesis. J. Bus. Res. 2016, 69, 2863-2872. [CrossRef]

68. Toivonen, M.; Tuominen, T. Emergence of innovations in services. Serv. Ind. J. 2009, 29, 887-902. [CrossRef]

69. Mou, W.; Wong, W.-K.; McAleer, M. Financial credit risk evaluation based on core enterprise supply chains. Sustainability 2018, 10, 3699. [CrossRef]

70. Liao, Z.; Shi, X.; Wong, W.-K. Key determinants of sustainable smartcard payment. J. Retail. Consum. Serv. 2014, 21, 306-313. [CrossRef]

71. Hipp, C.; Grupp, H. Innovation in the service sector: The demand for service-specific innovation measurement concepts and typologies. Res. Policy. 2005, 34, 517-535. [CrossRef] 
72. Skålén, P.; Gummerus, J.; Von Koskull, C.; Magnusson, P.R. Exploring value propositions and service innovation: A service-dominant logic study. J. Acad. Mark. Sci. 2015, 43, 137-158. [CrossRef]

73. Miozzo, M.; Soete, L. Internationalization of services: A technological perspective. Technol. Forecast. Soc. Chang. 2001, 67, 159-185. [CrossRef]

74. Lusch, R.F.; Nambisan, S. Service innovation: A service-dominant logic perspective. Mis Q. 2015, 39, $155-176$. [CrossRef]

75. Chesbrough, H. The logic of open innovation: Managing intellectual property. Calif. Manag. Rev. 2003, 45, 33-58. [CrossRef]

76. Wu, W.Y.; Chang, M.L.; Chen, C.W. Promoting innovation through the accumulation of intellectual capital, social capital, and entrepreneurial orientation. RD Manag. 2008, 38, 265-277. [CrossRef]

77. Arzubiaga, U.; Kotlar, J.; De Massis, A.; Maseda, A.; Iturralde, T. Entrepreneurial orientation and innovation in family SMEs: Unveiling the (actual) impact of the Board of Directors. J. Bus. Ventur. 2018, 33, 455-469. [CrossRef]

78. Bogaert, S.; Boone, C.; Declerck, C. Social value orientation and cooperation in social dilemmas: A review and conceptual model. Br. J. Soc. Psychol. 2008, 47, 453-480. [CrossRef]

79. Balliet, D.; Parks, C.; Joireman, J. Social value orientation and cooperation in social dilemmas: A meta-analysis. Group Process. Intergroup Relat. 2009, 12, 533-547. [CrossRef]

80. McClintock, C.G.; Allison, S.T. Social value orientation and helping behavior 1. J. Appl. Soc. Psychol. 1989, 19, 353-362. [CrossRef]

81. Pletzer, J.L.; Voelpel, S.C.; Van Lange, P. Selfishness Facilitates Deviance: The Link Between Social Value Orientation and Deviant Behavior. In Academy of Management Proceedings; Academy of Management: Briarcliff Manor, NY, USA, 2018; p. 12354.

82. Murphy, R.O.; Ackermann, K.A. Social value orientation: Theoretical and measurement issues in the study of social preferences. Personal. Soc. Psychol. Rev. 2014, 18, 13-41. [CrossRef]

83. Pletzer, J.L.; Balliet, D.; Joireman, J.; Kuhlman, D.M.; Voelpel, S.C.; Van Lange, P.A. Social value orientation, expectations, and cooperation in social dilemmas: A meta-analysis. Eur. J. Personal. 2018, 32, 62-83. [CrossRef]

84. Kreiser, P.M. Entrepreneurial orientation and organizational learning: The impact of network range and network closure. Entrep. Theory Pract. 2011, 35, 1025-1050. [CrossRef]

85. Alegre, J.; Chiva, R. Linking entrepreneurial orientation and firm performance: The role of organizational learning capability and innovation performance. J. Small Bus. Manag. 2013, 51, 491-507. [CrossRef]

86. Wang, E.S.-T.; Juan, P.-Y. Entrepreneurial orientation and service innovation on consumer response: A B\&B Case. J. Small Bus. Manag. 2016, 54, 532-545. [CrossRef]

87. Van Lange, P.A.; Vugt, M.V.; Meertens, R.M.; Ruiter, R.A. A Social Dilemma Analysis of Commuting Preferences: The Roles of Social Value Orientation and Trust 1. J. Appl. Soc. Psychol. 1998, 28, 796-820. [CrossRef]

88. Yan, B. Social Value Orientation, Social Influence and Crowdsourced Creativity. In Academy of Management Proceedings; Academy of Management: Briarcliff Manor, NY, USA, 2019; p. 13434. [CrossRef]

89. Wei, Z.; Zhao, Z.; Zheng, Y. Moderating effects of social value orientation on the effect of social influence in prosocial decisions. Front. Psychol. 2016, 7, 952. [CrossRef] [PubMed]

90. Declerck, C.H.; Bogaert, S. Social value orientation: Related to empathy and the ability to read the mind in the eyes. J. Soc. Psychol. 2008, 148, 711-726. [CrossRef]

91. Byrne, B.M. Structural Equation Modeling with AMOS: Basic Concepts, Applications, and Programming (Multivariate Applications Series); Taylor \& Francis Group: New York, NY, USA, 2010; Volume 396, p. 7384.

92. Hair, J.F.; Black, W.C.; Babin, B.J. Multivariate Data Analysis: A Global Perspective; Pearson Education: London, UK, 2010.

93. Gefen, D.; Straub, D.; Boudreau, M.-C. Structural equation modeling and regression: Guidelines for research practice. Commun. Assoc. Inf. Syst. 2000, 4, 7. [CrossRef]

94. Anderson, J.C.; Gerbing, D.W. Some methods for respecifying measurement models to obtain unidimensional construct measurement. J. Mark. Res. 1982, 19, 453-460. [CrossRef]

95. Hair, J.F.; Ringle, C.M.; Sarstedt, M. Partial least squares structural equation modeling: Rigorous applications, better results and higher acceptance. Long Range Plan. 2013, 46, 1-12. [CrossRef] 
96. Reeder, N.; O'Sullivan, C.; Tucker, S.; Ramsden, P.; Mulgan, G. Strengthening Social Innovation in Europe: Journey to Effective Assessment and Metrics; Enterprise and Industry, European Commission: Brussels, Belgium, 2012.

97. Parekh, N. 51 Questions on Social Entrepreneurship; Quad Press: Mountain View, CA, USA, 2015.

98. Tabachnick, B.G.; Fidell, L.S. Principal components and factor analysis. Using Multivar. Stat. 2001, 4, $582-633$.

99. Kaiser, H.F. A second generation little jiffy. Psychometrika 1970, 35, 401-415. [CrossRef]

100. Kaiser, H.F.; Rice, J. Little jiffy, mark IV. Educ. Psychol. Meas. 1974, 34, 111-117. [CrossRef]

101. Fornell, C.; Larcker, D.F. Evaluating structural equation models with unobservable variables and measurement error. J. Mark. Res. 1981, 18, 39-50. [CrossRef]

102. Anderson, J.C.; Gerbing, D.W. Structural equation modeling in practice: A review and recommended two-step approach. Psychol. Bull. 1988, 103, 411. [CrossRef]

103. Freixanet, J.; Braojos, J.; Rialp-Criado, A.; Rialp-Criado, J. Does international entrepreneurial orientation foster innovation performance? The mediating role of social media and open innovation. Int. J. Entrep. Innov. 2020. [CrossRef]

104. Carayannis, E.G.; Popescu, D.; Sipp, C.; Stewart, M. Technological learning for entrepreneurial development (TL4ED) in the knowledge economy (KE): Case studies and lessons learned. Technovation 2006, 26, 419-443. [CrossRef]

105. Shaw, E.; de Bruin, A. Reconsidering capitalism: The promise of social innovation and social entrepreneurship? Int. Small Bus. J. 2013, 31, 737-746. [CrossRef]

106. Wittmayer, J.; Backhaus, J.; Avelino, F.; Pel, B.; Strasser, T.; Kunze, I.; Zuijderwijk, L. Narratives of change: How social innovation initiatives construct societal transformation. Futures 2019, 112, 102433. [CrossRef]

107. Porter, M.E.; Kramer, M.R. The Big Idea: Creating Shared Value. How to reinvent capitalism-And unleash a wave of innovation and growth. Harv. Bus. Rev. 2011, 89, 62-77.

108. Stanford Social Innovation Review. 2020. Available online: https://ssir.org/about/overview (accessed on 11 March 2020).

109. Lee, J.-S.; Hsieh, C.-J. A research in relating entrepreneurship, marketing capability, innovative capability and sustained competitive advantage. J. Bus. Econ. Res. 2010, 8. [CrossRef]

110. Choi, S.; Choi, J.-S. Dynamics of innovation in nonprofit organizations: The pathways from innovativeness to innovation outcome. Hum. Serv. Organ. Manag. Leadersh. Gov. 2014, 38, 360-373. [CrossRef]

Publisher's Note: MDPI stays neutral with regard to jurisdictional claims in published maps and institutional affiliations.

(C) 2020 by the authors. Licensee MDPI, Basel, Switzerland. This article is an open access article distributed under the terms and conditions of the Creative Commons Attribution (CC BY) license (http://creativecommons.org/licenses/by/4.0/). 